\title{
Musings on social cohesion in South Africa
}

\author{
[ B O O K RE VIE W]
}

Ballantine, Christopher, Chapman, Michael, Erwin, Kira \& Maré, Gerhard (eds) (2017) (2015) Living together, living apart: Social cohesion in a future South Africa. Pietermaritzburg: UKZN Press. ISBN 978-186914-332-9 pbk. Pages vii +197

This slim volume offers a set of short essays on a range of topics, loosely bound together by the subtitle of the book - the question of social cohesion in South Africa. What does the phrase "social cohesion" mean, though? The editors ask this question at the outset, and conclude that it seems like a social goal that cannot be argued against (who would argue that "social cohesion" is a bad thing for a society to have?). For that reason, and because it appears to mean so much in governmental and intellectual circles in South Africa, the editors offer us the reflections of a diverse array of scholars and authors. Philosophy, Linguistics, Literature, Music, Legal Studies, Sociology, Developmental Studies, Genetics, Urban Geography, and Physics, are some of the home disciplines of the authors who apply themselves to the question(s) at hand.

From the 18 titles that the 20 individual contributors accord their essays, and from the diversity of disciplines already alluded to, it seems that the problematic of social cohesion can be addressed in a wide range of ways: studies of urban segregation (Marks), traditional leaders (chieftaincy, Thipe), xenophobia (Pillay), linguistic differences and bridging (Mesthrie), the

\section{Colin Tredoux}

Department of Psychology University of Cape Town Rondebosch 
dangers of epistemic relativism (Spurrett), music and fine art in the service of social change (Ballantine, and Schmahmann), the "hidden curriculum" of South African sport (Naidoo), sexual harassment and violence on South African campuses (Dugard \& Meyersfeld), and genetic variation and the unity of human "specieshood" (Soodyall \& Reagon), are some of the interesting topics addressed by the contributors. I was intrigued by the panorama of views in the volume: the message seems to me to be that issues of separateness and togetherness (a foundational binary or dialectic of social cohesion?) are to be found wherever one looks in South Africa, and should be addressed too in a multiplicity of ways. I also found a number of chapters that I would instinctively have associated with volumes on questions of separation and contact between social groups - an impassioned piece on inequality and its dangers for the future of SA (Maré), the central role of schools, universities, and educational policy in shaping a better future (Gardiner), and the connections between local questions of social cohesion and international "obligations" (eg, South Africa's curious record at the UNHRC of voting inconsistently on human rights abuses in other countries; Fritz). These disparate and interesting essays are bookended by a personal and quite beautiful piece by Njabulo Ndebele on re-thinking himself out of narrow categories like "black", "African", "comrade", and "citizen", and a moving piece by Jacob Dlamini on the gruesome death by burning of Jacob Dlamini, deputy Mayor the Lekoa Town Council, in 1984. (As far as I can see the names of the author and the victim are shared by coincidence; given the literary bent of many of the authors in the volume, I thought initially that we were in for an "Elizabeth Costello" moment in this particular chapter). Dlamini was killed because of his apparent collaboration and participation in apartheid local government structures, and after a reflection on how the Apartheid system exacted great damage on South Africa, at many levels, Jacob Dlamini, the author, concludes "... how to write about the many Jacob Dlaminis whose deaths remain unmourned in ways that might promote social cohesion - that is the ultimate challenge" ( $p$ 193), a moving phrase to end a volume on social cohesion in South Africa.

This is a very unusual volume. I find that there is merit in addressing questions of social separation and cohesion from a wide range of disciplines and perspectives, but all the contributions in the volume are brief, and most seem to me to be freeranging, and none offers much depth. Indeed, in several I wondered why the authors offered so little in the way of supporting evidence or data: was the point to reflect personally on the problems of social division, and separation in South Africa, and to see what many years of personal and academic experience might bring to the difficult problem of finding a point of departure? Perhaps this is the intention of the volume, and I certainly was intrigued in most of the essays by the reflections the authors offered. I found some quite profound, as I have indicated. 
I think this volume is worth reading - who would deny that social cohesion is important to all South Africans, and a topic that we should all reflect on? - and the reader will be rewarded, but I think it fair to say that it is a volume for casual reading rather than serious study. 